\title{
Locations for the best lidar view of mid-level and high clouds
}

\author{
Matthias Tesche ${ }^{1}$ and Vincent Noel $^{2}$ \\ ${ }^{1}$ Leipzig Institute for Meteorology, Leipzig University, Stephanstraße 3, 04103 Leipzig, Germany \\ ${ }^{2}$ Laboratoire d'Aérologie, CNRS/UPS, Observatoire Midi-Pyrénées, 14 avenue Edouard Belin, Toulouse, France
}

Correspondence: Matthias Tesche (matthias.tesche@uni-leipzig.de)

\begin{abstract}
.
Mid-level altocumulus clouds (Ac) and high cirrus clouds (Ci) can be considered as natural laboratories for studying cloud glaciation in the atmosphere. While their altitude makes them difficult to access with in-situ instruments, they can be conveniently observed from ground with active remote-sensing instruments such as lidar and radar. However, active remote sensing of $\mathrm{Ac}$ and $\mathrm{Ci}$ at visible wavelengths with lidar requires a clear line of sight between the instrument and the target cloud. It is therefore advisable to carefully assess potential locations for deploying ground-based lidar instruments in field experiments or for long-term observations that are focussed on mid-level or high clouds. Here, observations of clouds with two spaceborne lidars are used to assess where ground-based lidar measurements of mid- and upper level clouds are least affected by the lightattenuating effect of low-level clouds. It is found that cirrus can be best observed in the tropics, the Tibetan plateau, the western part of North America, the Atacama region, the southern tip of South America, Greenland, Antarctica, and parts of western Europe. For the observation of altocumulus clouds, a ground-based lidar is best placed on Greenland, Antarctica, the western flank of the Andes and Rocky Mountains, the Amazon, central Asia, Siberia, western Australia, or the southern half of Africa.
\end{abstract}

\section{Introduction}

Clouds have a strongly modulating effect on the radiative transport of energy in the atmosphere. They affect planetary albedo and, thus, the amount of solar radiation arriving at ground. Because it is hard to get to cloud level for direct measurements (Baumgardner et al., 2017), studies of cloud properties often resort to remote-sensing observations (Buehl et al., 2017) particularly to active remote sensing with lidar or cloud radar.

Since the beginning of atmospheric remote sensing with lidar, cirrus (Ci) clouds (Heymsfield et al., 2017) have been a focus of observational efforts Platt (1973, 1979); Sassen and Cho (1992); Sassen and Campbell (2001). Lidar has turned out to be the best option for long-term monitoring of cirrus occurrence as well as their optical and geometrical properties (Comstock et al., 2002; Seifert et al., 2007; Dupont et al., 2010; Hoareau et al., 2013; Kienast-Sjögren et al., 2016). In addition, observations of cirrus clouds have been used to demonstrate new lidar measurement techniques (Ansmann et al., 1992) and to validate the performance of spaceborne lidar instruments (Yorks et al., 2011). 
Altocumulus (Ac) clouds (Korolev et al., 2017) are often mixed-phase clouds that consist predominantly of supercooled liquid water droplets and, hence, are highly susceptible to the effect of ice nucleating particles (INPs). They therefore mark a natural laboratory for studies of heterogeneous glaciation in environments where efficient INPs are present. Polarization lidar measurements can be used to investigate the effect of mineral dust (Ansmann et al., 2005, 2008, 2009, 2019; Seifert et al., 2010), volcanic ash (Seifert et al., 2011), or other aerosol particle types (Kanitz et al., 2011; Seifert et al., 2015; Cheng and Yi, 2020; Radenz et al., 2021; Yi et al., 2021) acting as INP in the heterogeneous glaciation of altocumulus clouds.

However, active remote sensing of mid-level and high clouds with lidar at visible wavelengths requires a clear line of sight between the instrument and the target cloud. Particularly low-level liquid water clouds, that already attenuate the emitted laser light rather close to the ground, are a major obstacle for long-term observations of mid- and upper-level clouds. If a lidar was to be deployed for a field experiment or long-term observations that are focussed on mid-level or high clouds, it is advisable to carefully assess potential locations. Here, spaceborne lidar observations of clouds, for which the light-attenuation of low-level clouds has no effect on the detection of mid-level and high clouds, are used to assess where ground-based lidar measurements of altocumulus and cirrus are least affected by low-level cloudiness. The same methodology has already been used for finding locations at which tropospheric clouds are likely to have a minimum disturbing effect on the observation of Polar Tropospheric Clouds with ground-based lidar (Tesche et al., 2021). The used data and methodology is presented in Section 2. The results are shown and discussed in Section 3. The paper concludes with a summary in Section 4.

\section{Data and methodology}

\subsection{CALIPSO cloud profile data}

The Cloud-Aerosol Lidar with Orthogonal Polarization (CALIOP) lidar aboard the CALIPSO satellite Winker et al. (2009) is an elastic-backscatter lidar that operates at 532 and $1064 \mathrm{~nm}$. Since June 2006, CALIOP has become an invaluable tool for monitoring the three-dimensional distribution of aerosols and clouds in the troposphere and stratosphere. CALIPSO lidar measurements have been used to study the occurrence and properties of clouds. Such studies are often complemented with measurements of other instruments in the A-Train satellite constellation such as radiometers or cloud radar.

For this study, information on the extent and type of tropospheric clouds with a resolution of $5 \mathrm{~km}$ along the CALIPSO ground track and 30-m height bins below $8.2 \mathrm{~km}$ height (60-m height bins between 8.2 and $20.2 \mathrm{~km}$ height) is taken from the CALIPSO level 2 version 4.20 Cloud Profile product (05kmCPro.v4.20). The extracted parameters are time, latitude, longitude, the day-night flag, and the cloud type as provided in the Vertical Feature Mask. The data considered here cover the years 2010, 2011, 2012, 2015, 2018, and 2019. Table 1 gives an overview of the number of CALIPSO lidar profiles included in this study.

\subsection{CATS cloud profile data}

Based on the International Space Station (ISS), the Cloud-Aerosol Transport System (CATS, McGill et al. 2015) performed elastic-backscatter measurements at $1064 \mathrm{~nm}$ from February 2015 to October 2017 (Pauly et al., 2019). In contrast to CALIPSO, 
the orbit of the ISS has an inclination of $51.6^{\circ}$ and is not sun-synchronous. Therefore, CATS observations are restricted to latitudes lower than $51^{\circ}$ but allow for covering different times of the day. This latter capability is used here to assess the representativeness of cloud observations at the fixed CALIPSO times of 0130 and 1330 PM.

Two Level 2 CATS-ISS products were used to document the diurnal variability of clouds. The first is the L2O Profile product (05kmPro.v3.01), (Yorks et al., 2016a) which documents vertical profiles (at $60 \mathrm{~m}$ resolution) of various atmospheric properties every $5 \mathrm{~km}$ along the ISS ground track, mainly derived from the attenuated backscatter profiles measured by the CATS lidar at $1064 \mathrm{~nm}$. Profiles of feature type (Feature_Type_Fore_FOV, 1 indicating a cloud), and of cloud phase (Cloud_Phase_Fore_FOV, 3 indicating ice) for a given time, latitude, and longitude were used to derive a mask for ice clouds (Yorks et al., 2016b). From the L2O Layer product (05kmLay.v3.01), which documents layer-integrated properties for atmospheric features found in profiles of 1064-nm attenuated backscatter, the feature type (Feature_Type_Fore_FOV, 1 indicating a cloud), base and top altitude and pressure for each detected layer, and the profile opacity indicator (Percent_Opacity_Fore_FOV) were used to document the presence of altocumulus clouds. Those clouds were identified following the same criteria as in the CALIPSO scene classification (Liu et al., 2005): a non-opaque cloud layer with a top pressure between 440 and $680 \mathrm{hPa}$. For both products, it was required that the quality scores, that range between 0 and 10 , have to be larger than 5 for cloud identification.

A comparison between the fractions of cirrus and altocumulus clouds as inferred from the data sets of CALIPSO and CATS following the approaches described above is presented in the Appendix.

\subsection{Determination of cloudiness}

The CALIPSO retrieval separates between eight cloud types (Liu et al., 2009): (i) low overcast, transparent; (ii) low overcast, opaque; (iii) transition stratocumulus; (iv) low, broken cumulus; (v) altocumulus (transparent); (vi) altostratus (opaque); (vii) cirrus (transparent); and (viii) deep convective (opaque). For each profile, the number of height bins in which a certain cloud types was identified is summed up. The thus simplifies data set is then used to assess if a certain cloud type is present (total count per profile larger zero) or not.

In the analysis, two scenarios are considered. In the first setup, the data set is screened for cloudy profiles that show cirrus in the absence of opaque low- and mid-level clouds. These cases represent conditions under which cirrus could be detected by ground-based lidar without interference of lower clouds and will be referred to as isolated cirrus. The second setup refers to the possibility of detecting mid-level clouds with a ground-based lidar by screening the data set for profiles in which transparent altocumulus is identified without the presence of any of the four low-level cloud types below. Underlying low-level clouds need to be detected to achieve the aim of this study. Hence, opaque altocumulus is not included in the analysis of mid-level clouds.

The number of thus selected profiles is mapped on a grid of $2.50^{\circ}$ longitude by $1.25^{\circ}$ latitude to assess the occurrence rate of conditions for which a ground-based instrument could observe mid-level and high clouds without attenuation of the laser beam by clouds at lower levels.

The day-night flag is used to assess changes in cloud occurrence for CALIPSO overpasses during day and night. The annual variation is studied by compiling maps for the months December, January, February (DJF); March, April, May (MAM); June, 

Table 1 to provide an overview of the considered volume of data.

\section{Results}

\subsection{Cirrus clouds}

An overview of the occurrence of isolated cirrus as identified from six years of CALIPSO lidar measurements is provided in Figure 1. The land regions with the highest fraction of such CALIPSO profiles of 0.5 or larger are the Tibetan plateau, north-eastern Africa (Chad, Egypt, Libya, Sudan), Saharan Africa, California, northern Chile, and western Antarctica. Over water, the largest fractions are found over the Caribbean, the western Indian ocean, as well as in two bands north and south of the intertropical convergence zone (ITCZ). The distribution in Figure 1a changes considerable if the number of CALIPSO profiles that show isolated cirrus is normalized by the number of cirrus-containing cloudy profiles (Figure 1b) rather than all cloudy CALIPSO profiles (Figure 1a). The absolute number of cirrus-containing CALIPSO profiles in Figure 1c shows that regions with a high coverage of isolated cirrus in Figure 1a and b, such as north-eastern Africa and California, actually feature a rather low occurrence rate of cirrus-containing CALIPSO profiles. Combining the information in Figure 1 reveals that the land sites with the best temporal coverage for observing isolated cirrus clouds from ground have to feature (i) a large ratio of cirrus observations in the absence of low- and mid-level clouds with (ii) a high occurrence rate of cirrus-containing profiles.

A separation with respect to CALIPSO observations during day (overpasses at 1330 local time) and night (overpasses at 0130 local time) is provided in Figure 2. The differences in this figure are likely related to the combined effect of diurnal variability and variations in detection sensitivity. The increased detection sensitivity during night (related to the absence of background noise from scattered sunlight) generally leads to an increase in the number of cirrus-containing cloudy profiles south of about $55^{\circ} \mathrm{N}$ while the opposite is the case at higher latitudes (not shown). Nevertheless, the patterns of cirrus occurrence for CALIPSO observations during day and night do not differ much from the overall pattern in figure Figure 1a.

The seasonal variation of the occurrence of isolated cirrus clouds is presented in Figure 3. The region with the by far highest occurrence rate of isolated cirrus clouds is northern Africa during boreal winter. Other regions of pronounced seasonal variation are the west coast of North America, Chile, the southern tip of Africa, the Arabian peninsula, the Indian Ocean and the Indian subcontinent, Tibet and western China, the maritime continent, and the equatorial Pacific Ocean. In contrast to these regions, seasonal variations at the poles are the result of the effect of polar night and day. This can also be seen from comparing Figures 1 and 2.

\subsection{Mid-level clouds}

The map of the occurrence of transparent mid-level clouds that would be detectable with a ground-based lidar from six years of CALIPSO data is presented in Figure 4. The land regions with the highest fraction of CALIPSO profiles that contain transparent altocumulus clouds without low-level clouds below are the Greenland ice sheet, eastern Antarctica, the western 
flanks of the Rocky Mountains and Andes, western Australia, southern Africa and the Horn of Africa, large parts of the Middle East, and the area around the Himalayas. Figures $4 \mathrm{~b}$ and $\mathrm{c}$ reveal that cloudy profiles that contain transparent altocumulus are dominating over the continents and the equatorial oceans. A similar finding is presented in Bourgeois et al. (2016). In contrast, transparent altocumulus generally occurs less frequently over mid-latitude oceans and the stratocumulus decks to the west of the continents, though aircraft measurements have shown that the occurrence rate of thin mid-level clouds is non-negligible in these regions (Adebiyi et al., 2020).

The day-night contrast for altocumulus clouds in Figure 5 is more pronounced than the one for isolated cirrus in Figure 2 with a larger occurrence rate of continental transparent altocumulus clouds without low-level clouds underneath during daytime. This is particularly visible over western North America, southern and eastern Africa, eastern Antarctica, and western Australia. A slight increase in the occurrence rate is found over the equatorial oceans during night, again likely as a result of increased detection sensitivity in the absence of the solar background. The occurrence rate is lowest over the regions of dense stratocumulus decks to the west of the continents.

Figure 6 reveals that some regions show a considerable change in the occurrence rate of transparent altocumulus over the year. This seasonal variation would need to be considered in the choice of location for ground-based lidar observations of mid-level clouds and in the interpretation of the collected data. For instance, ground-based lidar measurements of transparent altocumulus clouds located in northern Afrcia, the Middle East, or at the west coast of North America are likely to give the best yield in observations during summer, while the occurrence of those clouds is considerably lower during other seasons. in contrast, the opposite is found for Eastern Africa. Occurrence rates are relatively constant over the southern part of Africa, the Atacama region, Greenland, western Australia, and central Asia.

\subsection{Diurnal variability}

An extensive comparison of the findings from observations with the CATS and CALIPSO lidars is provided in the Appendix. Here, the capability of CATS to cover the diurnal variability in cloudiness in the latitude band from $51^{\circ} \mathrm{S}$ to $51^{\circ} \mathrm{N}$ (Noel et al., 2018) is used to evaluate the representativeness of the CALIPSO lidar observations at 0130 and 1330 local time for drawing conclusions regarding the most suitable regions for observing mid-level and high clouds with ground-based lidar instruments.

Figure 7 presents the analysis of CATS observations over its full period of operation from March 2015 to October 2017. Though compiled with a coarser resolution, the map of the occurrence rate of isolated cirrus clouds in Figure $7 \mathrm{a}$ can be compared directly to the CALIPSO observations in Figure 1a. Data from both instruments give a very similar global distribution of isolated cirrus clouds with clear maxima of occurrence over northern Africa and the Tibetan plateau. It is therefore reasonable to make use of both time series for a more comprehensive analysis of the best locations for observing mid-level and high clouds with ground-based lidar. The anomaly in the diurnal variation of the zonal mean occurrence rate of isolated ice clouds over all surfaces in Figure 7b reveals that noontime measurements in the northern hemisphere show lower values than the daily average of CATS observations while the opposite is the case for evening measurements. Much smaller variation from the daily average is found in the first six to nine hours of a day. A similar picture is found when looking at zonal mean values for different seasons (not shown). The diurnal variation in zonal bands of $20^{\circ}$ is shown in Figure 7d. Over all surfaces, measurements in 
the tropics show the largest anomaly at noon and in the evening. Smaller variations are found at lower and mid-latitudes. All zonal bands show mean values varying around zero until 0600 . Figure $7 \mathrm{c}$ shows that the diurnal variation is intensified when considering only data over land - which are the areas where a ground-based lidar would be placed. In that case, a stronger negative anomaly is found around noon compared to the data over all surfaces in Figure 7b, while a positive anomaly extends from 1800 to 0600, though weakening after midnight. This is also corroborated by the zonal means over land in Figure 7d, which reveal the smallest anomaly during the morning hours. From this investigation of diurnal variation and the magnitude of the anomaly during day and night, it can be concluded that CALIPSO night time observations at 0130 local time might be more representative for an objective assessment of the ideal regions for observing mid-level and high clouds with ground-based lidar instruments compared to daytime observations at 1330 local time.

The results of an analogous investigation for transparent altocumulus clouds are presented in Figure 8. Again, the distribution of isolated altocumulus clouds from CATS observations resembles that derived from the CALIPSO time series in Figure 4a. However, the smaller volume of the CATS data set in combination with the coarser resolution of the spatial gridding lead to a weaker contrast in altocumulus occurrence in Figure 8a compared to the CALIPSO data in Figure 4a. The anomaly in the diurnal variation of the zonal mean occurrence rate of isolated altocumulus is much weaker than for cirrus for observations over all surfaces as well as land only. In fact, the anomaly is negligible when considering all surfaces (Figure $8 \mathrm{~b}$ and d). Considering only data over land shows a weak positive anomaly around noon and an even weaker negative anomaly between 1800 and 0600 (Figure 8c). Hence, CALIPSO observations at 0130 local time should be representative for the better part of a day.

\subsection{Placing a ground-based lidar for observations of high and mid-level clouds}

The findings of this study are summarized in Figure 9. The combination of (i) the ratio of CALIPSO profiles that contain cirrus clouds in the absence of opaque low- and mid-level clouds versus all cloudy profiles with (ii) the normalized number of CALIPSO profiles per grid box is used to identify those land regions where measurements with a ground-based lidar are most likely to yield the highest possible observation rate for studying mid-level and high clouds.

Unsurprisingly, cirrus clouds are best observed in the tropics with particularly suitable conditions for ground-based lidar measurements at the northern coast of South America, equatorial Africa, the southern tip of the Indian subcontinent, and the maritime continent. Cirrus observations with lidar in this regions have been performed for instance in Niger (Protat et al., 2010), in southern India (Pandit et al., 2015), at the Maldives (Seifert et al., 2007), and at Nauru (Comstock et al., 2002). Further favourable regions are the Tibetan plateau (Dai et al., 2019; He et al., 2013) and western China, western North America (Sassen and Campbell, 2001; Sassen and Benson, 2001), Florida and the Caribbean (Haarig et al., 2016), the Atacama region, the southern tip of South America (Barja Gonzalez et al., 2020), the Amazon rain forest (Gouveia et al., 2017), Antarctica (Alexander and Klekociuk, 2021), and Greenland (Lacour et al., 2018), where semi-transparent clouds were found to potentially enhance ice sheet melting (Bennartz et al., 2013; Solomon et al., 2017). Less ideal conditions are met over Europe (Giannakaki et al., 2007; Kienast-Sjögren et al., 2016) and most of Asia. The worst regions are the Canadian Arctic, the northern coast of Europe and Asia, the Middle East, southern Africa, and most of Australia. Nevertheless, studies have been published based on measurements at those regions as well, e.g. Platt (1973), Protat et al. (2010). 
The preferential regions for observing mid-level clouds with ground-based lidar are shown in Figure 9b. These turn out to be more confined compared to the ones for cirrus in Figure 9a. The regions that stick out are the Greenland plateau and Antarctica (Del Guasta et al., 1993), where the topography is too high to have low-level clouds as an obstacle for lidar measurements. At low and mid-latitudes, good observational conditions prevail at the western flanks of the Rocky Mountain (Sassen, 2002) and Andes mountain ranges (Kanitz et al., 2011; Jimenez et al., 2020), over the Amazon, western Australia (Protat et al., 2011), southern and eastern Africa, the Gulf region, the fringe of the Tibetan plateau, and central Asia. The regions indicated in Figure 9b mark those for which a ground-based lidar is likely to give the best return rate in terms of observing altocumulus clouds. This is particularly important for short-term deployments such as field experiments which typically extend over a period of a few weeks to months. Alternatively, long-term measurements are the best option for collecting a volume of data that is sufficient to allow for identifying specific case studies as well as for enabling a statistical analysis of the observed altocumulus clouds - even in regions that are not emphasised in Figure 9b, such as central Europe (Ansmann et al., 2005; Seifert et al., 2010; Schmidt et al., 2015).

\section{Summary and conclusions}

Six years of measurements with the polar orbiting CALIPSO lidar have been used in combination with 32 months of measurements with the CATS lidar aboard the International Space Station between March 2015 and October 2017 to investigate the global distribution of cloud scenarios that support the observation of mid-level and high clouds with ground-based lidar instruments. The CALIPSO cloud mask was used to select profiles in which

1. cirrus clouds are observed in the absence of low-level clouds and opaque altocumulus underneath and

2. transparent altocumulus is observed in the absence of low-level clouds underneath

as an analogue for conditions under which a ground-based lidar could be used for unperturbed observations of high and midlevel clouds, respectively.

The fixed CALIPSO overpass times at 0130 and 1330 local time inhibit an assessment of the diurnal variation in cloudiness. Hence, observations with the CATS lidar have been used to investigate the representativeness of the CALIPSO cloud sampling. In contrast to the CALIPSO data set, the CATS data set does not feature a cloud flag. Scenarios that are comparable to the ones selected from the CALIPSO observations have been compiled by screening the data set for the occurrence of cloud ice and for the location of cloud base and top heights.

The analysis of the data sets from the two spaceborne lidars shows a remarkable resemblance of the regional and vertical distribution of isolated cirrus and altocumulus clouds despite the different approaches to extract the corresponding information from the corresponding data sets. The diurnal variation of cloud occurrence from the CATS data set leads to the conclusion that CALIPSO observations at 0130 local time are representative for the better part of the day while the period of largest anomaly is covered by the overpass at 1330 local time. Generally, diurnal anomalies in cloud occurrence are (i) stronger over land compared to over all surfaces and (ii) stronger for isolated cirrus clouds compared to isolated altocumulus clouds. The ratio of 
occurrence of the two cloud types versus all cloudy profiles per grid box in combination with the absolute number of profiles in a corresponding grid box is used to identify those regions for which a ground-based lidar is likely to encounter the best balance between the occurrence of the desired cloud types and the prevalence of favourable conditions to actually observe these clouds, i.e. the absence of strongly light-attenuating clouds below the target cloud. This information is particularly vital in the planning of deploying lidar instruments in the framework of field experiments or measurement campaigns. Such deployments generally last between only a few weeks to several months and their success relies strongly on finding atmospheric conditions that meet the desired research objectives to allow for addressing related science questions. From the approach used in this study, it is found that the best regions for lidar measurements of cirrus clouds are the tropics, the Tibetan plateau, the western part of North America, the Atacama region, the southern tip of South America, Greenland, Antarctica, and parts of western Europe. For the observation of altocumulus clouds, a ground-based lidar is best placed on Greenland, Antarctica, the western flank of the Andes and Rocky Mountains, the Amazon, central Asia, Siberia, western Australia, or the southern half of Africa. Finally, it should be emphasized that the regions above provide the best gain of a lidar deployment. However, this advantage for short-term deployments can be compensated by increasing the length of a lidar operating at a certain site as this increases the likelihood of meeting the desired atmospheric conditions for observing a targeted cloud type.

Data availability. All spaceborne lidar data used in this study are openly available, e.g. through the ICARE Data and Services Center at https: //www.icare.univ-lille.fr/. More specifically, the CALIPSO Cloud profile data (CALIPSO Cloud Profile product, 2022) used in this study are located at https://www.icare.univ-lille.fr/data-access/data-archive-access/?dir=CALIOP/05kmCPro.v4.20/ while the CATS data (CATS Layer product, 2022; CATS Profile product, 2022) can be found at https://www.icare.univ-lille.fr/data-access/data-archive-access/?dir= CATS/CATS-ISS_L2O_N-M7.2_05kmLay.v3.01/and https://www.icare.univ-lille.fr/data-access/data-archive-access/?dir=CATS/CATS-ISS_ L2O_N-M7.2_05kmPro.v3.01/.

\section{Appendix A: Comparability of CALIPSO and CATS observations of the fraction of high and mid-level clouds}

The consistency of observations with the CALIPSO and CATS lidars was investigated for the time period from March 2015 to October 2017, i.e. the period of CATS operation. For this Appendix, CATS observations of ice and mid-level clouds collected in a time period of $\pm 1 \mathrm{~h}$ around the CALIPSO observations at 0130 and 1330 local time were used to derive cloud fraction (i) in grid boxes of $5^{\circ}$ by $5^{\circ}$, (ii) as latitudinal and longitudinal averages, and (iii) in the form of height profiles for comparison with CALIPSO observations. Note that the temporal constraint leads to a much lower number of CATS profiles compared to the CALIPSO observations and, thus, more noise in the CATS data.

\section{A1 Cirrus clouds}

Figure A1 compares the spatial distribution of the occurrence rate of cirrus clouds as seen by CALIPSO and CATS. Both data sets agree in their main features, i.e. maxima of ice cloud fraction over the tropics, regions of low ice cloud fraction in bands 
around $30^{\circ} \mathrm{N}$ and $30^{\circ} \mathrm{N}$, and an increase in ice cloud fraction towards higher latitudes from there. This is confirmed when considering latitudinal and longitudinal averages (not shown). The CATS and CALIPSO data sets agree in the magnitude of latitudinally averaged ice cloud fraction with the largest deviation of about 0.05 in the band at $25^{\circ} \mathrm{S}-$ an effect that might be resulting from the noise in the CATS data. The longitudinally averaged ice cloud fraction shows bands with a larger deviation between the two data sets (from $150^{\circ} \mathrm{W}$ to $120^{\circ} \mathrm{W}$ and from $50^{\circ} \mathrm{W}$ to $50^{\circ} \mathrm{E}$ ) as well as bands for which the averages overlay almost perfectly. Again, noise induced from the decreased amount of grid boxes for for deriving the values is likely to affect the comparison. Both instruments reveal in almost identical vertical distribution of ice clouds (not shown) within the latitude band between $\pm 5^{\circ}$ (where they feature a roughly similar sampling rate). This agreement corroborates the findings of Sellitto et al. (2020).

Figure A1 refers to all ice clouds. For a fair comparison with the CALIPSO data in Figure 1a, i.e. clouds that are (i) flagged as cirrus and (ii) are the only cloud type in the profile, the CATS data set has been screened for what is referred to here as isolated cirrus clouds. The cloud subtype classification is not available in the CATS data set. However, when only ice clouds are present in a profile (i.e., they are not the top of a larger system or part of a mixed-phase system) and these clouds are not flagged as opaque, they are most likely to be cirrus. The CALIPSO Atmospheric_Volume_Description variable and the CATS Percent_Opacity_Fore_FOV variable were used to select clouds that are neither opaque nor fully attenuated.

Figures A2 shows that the vertical profile as well as the zonal average of the fraction of isolated ice clouds as seen by CATS match those seen by CALIPSO very closely. About 75\% to 95\% of isolated ice clouds between 7.5 and $17.5 \mathrm{~km}$ height were categorised as cirrus. Moreover, $88 \%$ of profiles containing isolated ice clouds in CALIPSO data between $51^{\circ} \mathrm{S}$ and $51^{\circ} \mathrm{N}$ are categorised as cirrus $\left(92 \%\right.$ for $30^{\circ} \mathrm{S}$ to $\left.30^{\circ} \mathrm{N}\right)$. This fraction decreases towards higher latitudes beyond the area of CATS data coverage between $51^{\circ} \mathrm{S}$ and $51^{\circ} \mathrm{N}$. The findings in Figures A2 suggest that the majority of isolated ice clouds in non-opaque CATS profiles are equivalent to isolated cirrus in CALIPSO data. In addition, cloud-fraction retrievals for isolated ice clouds in non-opaque profiles give comparable results when using data from the CALIPSO and CATS instruments. As a consequence, the investigation of the diurnal variability of ice clouds considers CATS profiles that contain isolated ice clouds and are not opaque, and assumes that these profiles are equivalent to CALIPSO profiles that contain isolated cirrus clouds.

\section{A2 Mid-level clouds}

Figure A3 compares the spatial distribution of the occurrence rate of transparent mid-level clouds as seen by CALIPSO and CATS during the CATS period of operation. Overall, the occurrence rate is much lower than for ice clouds in Figure A1. In addition, transparent altocumulus is observed primarily over land. Both time series resolve comparable regions of high Ac occurrence rate over southern and eastern Africa, the Middle East, central Asia, western Australia, the Amazon, coastal Peru, and to the west of the Rocky Mountains. Discernible differences are restricted to northern Africa, central Asia, and eastern Australia - all regions where CATS finds slightly a higher Ac occurrence rate than CALIPSO..

Figure A4a shows that the small differences in Figures A3 don't lead to a large deviation in the zonal mean altocumulus fraction. The only exception is visible around $40^{\circ} \mathrm{N}$ where the higher Ac occurrence rates over western North America and central Asia in CATS observations compared to CALIPSO leads to a higher zonal mean in the CATS data set. The vertical 
https://doi.org/10.5194/amt-2022-34

Preprint. Discussion started: 10 February 2022

(c) Author(s) 2022. CC BY 4.0 License.

(c) (i)

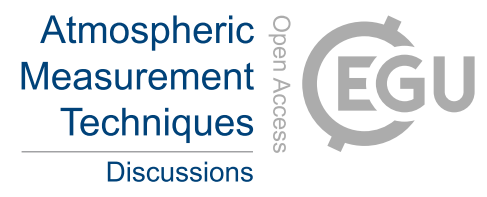

285 distribution of Ac fraction in Figure A4b shows that both instruments place the target clouds within the same height range with a maximum at around $5 \mathrm{~km}$ height but a larger Ac fraction in the CALIPSO data set compared to the one derived from CATS measurements.

Author contributions. MT conceived this study, and processed and analysed the CALIPSO data. VN processed and analysed the CATS data. Both authors contributed equally to the discussion of the findings, the writing of the paper, and the creation of the figures.

Competing interests. The authors declare no competing interests.

Acknowledgements. This work was supported by the Franco-German Fellowship Programme on Climate, Energy, and Earth System Research (Make Our Planet Great Again - German Research Initiative, MOPGA-GRI) of the German Academic Exchange Service (DAAD), funded by the German Ministry of Education and Research. VN acknowledges funding by CNES and CNRS and would like to thank the IPSL ESPRI and AERIS computation facilities for data storage and analysis capacity. We thank the AERIS/ICARE Data and Services Center (https://www.icare.univ-lille.fr/) for providing access to the data used in this study. 


\section{References}

Adebiyi, A. A., Zuidema, P., Chang, I., Burton, S. P., and Cairns, B.: Mid-level clouds are frequent above the southeast Atlantic stratocumulus clouds, Atmos. Chem. Phys., 20, 11025-11043, https://doi.org/10.5194/acp-20-11025-2020, 2020.

Alexander, S. P. and Klekociuk, A. R.: Constraining Ice Water Content of Thin Antarctic Cirrus Clouds Using Ground-Based Lidar and Satellite Data, J. Atmos. Sci., 78, 1791-1806, https://doi.org/10.1175/JAS-D-20-0251.1, 2021.

Ansmann, A., Wandinger, U., Riebesell, M., Weitkamp, C., and Michaelis, W.: Independent measurement of extinction and backscatter profiles in cirrus clouds by using a combined Raman elastic-backscatter lidar, Appl. Opt., 31, 7113-7131, https://doi.org/10.1364/AO.31.007113, 1992.

Ansmann, A., Mattis, I., Müller, D., Wandinger, U., Radlach, M., Althausen, D., and Damoah, R: Ice formation in Saharan dust over central Europe observed with temperature/humidity/aerosol Raman lidar, J. Geophys. Res., 110, D18S12, https://doi.org/10.1029/2004JD005000, 2005 .

Ansmann, A., Tesche, M., Althausen, D., Müller, D., Freudenthaler, V., Heese, B., Wiegner, M., Pisani, G., Knippertz, P., and Dubovik, O.: Influence of Saharan dust on cloud glaciation in southern Morocco during SAMUM, J. Geophys. Res., 113, D04210, https://doi.org/10.1029/2007JD008785, 2008.

Ansmann, A., Tesche, M., Seifert, P., Althausen, D., Engelmann, R., Fruntke, J., Wandinger, U., Mattis, I., and Müller, D.: Evolution of the ice phase in tropical altocumulus: SAMUM lidar observations over Cape Verde, J. Geophys. Res., 114, D17208, https://doi.org/10.1029/2008JD011659, 2009.

Ansmann, A., Mamouri, R.-E., Bühl, J., Seifert, P., Engelmann, R., Hofer, J., Nisantzi, A., Atkinson, J. D., Kanji, Z. A., Sierau, B., Vrekoussis, M., and Sciare, J.: Ice-nucleating particle versus ice crystal number concentration in altocumulus and cirrus layers embedded in Saharan dust:a closure study, Atmos. Chem. Phys., 19, 15087-15115, https://doi.org/10.5194/acp-19-15087-2019, 2019.

Barja Gonzalez, B., Seifert, P., Gouveia, D. A., Zamorano, F., and Rosas, J.: Characterization of cirrus clouds at the southern hemisphere mid-latitude site of Punta Arenas (53 ${ }^{\circ}$ S, $71^{\circ}$ W), In AGU Fall Meeting Abstracts, vol. 2020, pp. A033-0012, 2020.

Baumgardner, D., Abel, S. J., Axisa, D., Cotton, R., Crosier, J., Field, P., Gurganus, C., Heymsfield, A., Korolev, A., Krämer, M., Lawson, P., McFarquhar, G., Ulanowski, Z., and Um, J.: Cloud Ice Properties: In Situ Measurement Challenges, Meteorolog. Monogr., 58, 9.1-9.23, https://doi.org/10.1175/AMSMONOGRAPHS-D-16-0011.1, 2017.

Bennartz, R., Shupe, M., Turner, D., Walden, V. P., Steffen, K., Cox, C. J., Kulie, M. S., Miller, N. B., and Pettersen, C.: July 2012 Greenland melt extent enhanced by low-level liquid clouds, Nature, 496, 83-86, https://doi.org/10.1038/nature12002, 2013.

Bourgeois, Q., Ekman, A., Igel, M., and Krejci, R: Ubiquity and impact of thin mid-level clouds in the tropics. Nat. Commun. 7, 12432 (2016). https://doi.org/10.1038/ncomms 12432

Bühl, J., Alexander, S., Crewell, S., Heymsfield, A., Kalesse, H., Khain, A., Maahn, M., Van Tricht, K., and Wendisch, M.: Remote Sensing, Meteorol. Monogr., 58, 10.1-10.21, https://doi.org/10.1175/AMSMONOGRAPHS-D-16-0015.1, 2017.

CALIPSO Cloud Profile Product, https://www-calipso.larc.nasa.gov/resources/calipso_users_guide/data_summaries/profile_data.php (last access: 10 January 2022).

Cloud-Aerosol Transport System (CATS) International Space Station (ISS) Level 2 Operational Night Mode 7.2 Version 3-01 5 km Layer data product, doi:10.5067/ISS/CATS/L2O_N-M7.2-V3-01_05kmLay (last access: 10 January 2022).

Cloud-Aerosol Transport System (CATS) International Space Station (ISS) Level 2 Operational Night Mode 7.2 Version 3-01 5 km Profile data product, doi:10.5067/ISS/CATS/L2O_N-M7.2-V3-01_05kmPro (last access: 10 January 2022). 
https://doi.org/10.5194/amt-2022-34

Preprint. Discussion started: 10 February 2022

(c) Author(s) 2022. CC BY 4.0 License.
Atmospheric

Measurement

Techniques

Discussions

Cheng, C. and Yi, F.: Falling mixed-phase ice virga and their liquid parent cloud layers as observed by ground-based lidars, Remote Sens. 2020, 12, 2094, https://doi.org/10.3390/rs12132094, 2020.

Comstock, J. M., Ackerman, T. P., and Mace, G. G.: Ground-based lidar and radar remote sensing of tropical cirrus clouds at Nauru Island: Cloud statistics and radiative impacts, J. Geophys. Res., 107, 4714, https://doi.org/10.1029/2002JD002203, 2002.

Dai, G., Wu, S., Song, X., and Liu, L.: Optical and Geometrical Properties of Cirrus Clouds over the Tibetan Plateau Measured by LiDAR and Radiosonde Sounding during the Summertime in 2014, Remote Sens., 11, https://doi.org/10.3390/rs11030302, 2019.

Del Guasta, M., Morandi, M., Stefanutti, L., Brechet, J., and Piquad, J.: One year of cloud lidar data from Dumont d’Urville (Antarctica): 1.

General overview of geometrical and optical properties, J. Geophys. Res., 98, 18575-18587, https://doi.org/10.1029/93JD01476, 1993.

Dupont, J. C., Haeffelin, M., Morille, Y., Noel, V., Keckhut, P., Winker, D., Comstock, J., Chervet, P., and Roblin, A.: Macrophysical and optical properties of midlatitude cirrus clouds from four ground-based lidars and collocated CALIOP observations, J. Geophys. Res., 115, D00H24, https://doi.org/10.1029/2009JD011943, 2010.

Giannakaki, E., Balis, D. S., Amiridis, V., and Kazadzis, S.: Optical and geometrical characteristics of cirrus clouds over a Southern European lidar station, Atmos. Chem. Phys., 7, 5519-5530, https://doi.org/10.5194/acp-7-5519-2007, 2007.

Gouveia, D. A., Barja, B., Barbosa, H. M. J., Seifert, P., Baars, H., Pauliquevis, T., and Artaxo, P.: Optical and geometrical properties of cirrus clouds in Amazonia derived from 1 year of ground-based lidar measurements, Atmos. Chem. Phys., 17, 3619-3636, https://doi.org/10.5194/acp-17-3619-2017, 2017.

Haarig, M., Engelmann, R., Ansmann, A., Veselovskii, I., Whiteman, D. N., and Althausen, D.: 1064-nm rotational Raman lidar for particle extinction and lidar-ratio profiling: cirrus case study, Atmos. Meas. Tech., 9, 4269-4278, https://doi.org/10.5194/amt-9-4269-2016, 2016.

He, Q. S., Li, C. C., Ma, J. Z., Wang, H. Q., Shi, G. M., Liang, Z. R., Luan, Q., Geng, F. H., and Zhou, X. W.: The Properties and Formation of Cirrus Clouds over the Tibetan Plateau Based on Summertime Lidar Measurements, J. Atmos. Sci., 70, 901-915, https://doi.org/10.1175/JAS-D-12-0171.1, 2013.

Heymsfield, A. J., Krämer, M., Luebke, A., Brown, P., Cziczo, D. J., Franklin, C., Lawson, P., Lohmann, U., McFarquhar, G., Ulanowski, Z., and Van Tricht, K.: Cirrus Clouds, Meteorolog. Monogr., 58, 2.1-2.26, https://doi.org/10.1175/AMSMONOGRAPHS-D-16-0010.1, 2017.

Hoareau, C., Keckhut, P., Noel, V., Chepfer, H., and Baray, J.-L.: A decadal cirrus clouds climatology from ground-based and spaceborne lidars above the south of France (43.9 $\left.\mathrm{N}-5^{\circ} .7^{\circ} \mathrm{E}\right)$, Atmos. Chem. Phys., 13, 6951-6963, https://doi.org/10.5194/acp-13-6951-2013, 2013.

Jimenez, C., Ansmann, A., Engelmann, R., Donovan, D., Malinka, A., Seifert, P., Wiesen, R., Radenz, M., Yin, Z., Bühl, J., Schmidt, J., Barja, B., and Wandinger, U.: The dual-field-of-view polarization lidar technique: a new concept in monitoring aerosol effects in liquid-water clouds - case studies, Atmos. Chem. Phys., 20, 15265-15284, https://doi.org/10.5194/acp-20-15265-2020, 2020.

Kanitz, T., Seifert, P., Ansmann, A., Engelmann, R., Althausen, D., Casiccia, C., and Rohwer, E. G.: Contrasting the impact of aerosols at northern and southern midlatitudes on heterogeneous ice formation, Geophys. Res. Lett., 38, L17802, https://doi.org/10.1029/2011GL048532, 2011.

Kienast-Sjögren, E., Rolf, C., Seifert, P., Krieger, U. K., Luo, B. P., Krämer, M., and Peter, T.: Climatological and radiative properties of midlatitude cirrus clouds derived by automatic evaluation of lidar measurements, Atmos. Chem. Phys., 16, 7605-7621, https://doi.org/10.5194/acp-16-7605-2016, 2016. 
https://doi.org/10.5194/amt-2022-34

Preprint. Discussion started: 10 February 2022

(c) Author(s) 2022. CC BY 4.0 License.
Atmospheric

Measurement

Techniques

Discussions

Korolev, A., McFarquhar, G., Field, P. R., Franklin, C., Lawson, P., Wang, Z., Williams, E., Abel, S. J., Axisa, D., Borrmann, S., Crosier, J.,

Fugal, J., Krämer, M., Lohmann, U., Schlenczek, O., Schnaiter, M., and Wendisch, M.: Mixed-Phase Clouds: Progress and Challenges, Meteorolog. Monogr., 58, 5.1-5.50, https://doi.org/10.1175/AMSMONOGRAPHS-D-17-0001.1, 2017.

Lacour, A., Chepfer, H., Miller, N. B., Shupe, M. D., Noel, V., Fettweis, X., Gallee, H., Kay, J. E., Guzman, R., and Cole, J.: How Well Are Clouds Simulated over Greenland in Climate Models? Consequences for the Surface Cloud Radiative Effect over the Ice Sheet, Journal of Climate, 31, 9293-9312, https://doi.org/10.1175/JCLI-D-18-0023.1, 2018.

Liu, Z., Omar, A. H., Hu, Y., Vaughan, M. A., and Winker, D. M.: CALIOP algorithm theoretical basis document-Part 3: Scene classification algorithms. Release 1.0, PC-SCI-202, NASA Langley Research Center, Hampton, VA, 56 pp., available at http://wwwcalipso.larc.nasa.gov/resources/pdfs/PC-SCI-202_Part3_v1.0.pdf (last access: 13 December 2021), 2005.

Liu, Z., Vaughan, M., Winker, D., Kittaka, C., Getzewich, B., Kuehn, R., Omar, A., Powell, K., Trepte, C., and Hostetler, C.: The CALIPSO lidar cloud and aerosol discrimination: Version 2 algorithm and initial assessment of performance, J. Atmos. Ocean. Tech., 26, 1198-1213, 2009.

McGill, M. J., Yorks, J. E., Scott, V. S., Kupchock, A. W., and Selmer, P. A.: The Cloud-Aerosol Transport System (CATS): a technology demonstration on the International Space Station, Proc. Spie., 9612, 96120A, https://doi.org/10.1117/12.2190841, 2015.

Noel, V., Chepfer, H., Chiriaco, M., and Yorks, J.: The diurnal cycle of cloud profiles over land and ocean between $51^{\circ} \mathrm{S}$ and $51^{\circ} \mathrm{N}$, seen by the CATS spaceborne lidar from the International Space Station, Atmos. Chem. Phys., 18, 9457-9473, https://doi.org/10.5194/acp-189457-2018, 2018.

Pandit, A. K., Gadhavi, H. S., Venkat Ratnam, M., Raghunath, K., Rao, S. V. B., and Jayaraman, A.: Long-term trend analysis and climatology of tropical cirrus clouds using 16 years of lidar data set over Southern India, Atmos. Chem. Phys., 15, 13833-13848, https://doi.org/10.5194/acp-15-13833-2015, 2015.

Pauly, R. M., Yorks, J. E., Hlavka, D. L., McGill, M. J., Amiridis, V., Palm, S. P., Rodier, S. D., Vaughan, M. A., Selmer, P. A., Kupchock, A. W., Baars, H., and Gialitaki, A.: Cloud-Aerosol Transport System (CATS) $1064 \mathrm{~nm}$ calibration and validation, Atmos. Meas. Tech., 12 , 6241-6258, https://doi.org/10.5194/amt-12-6241-2019, 2019.

Platt, C.M.R.: Lidar and Radiometric Observations of Cirrus Clouds, J. Atmos. Sci., 30, 1191-1204, https://doi.org/10.1175/15200469(1973)030<1191:LAROOC>2.0.CO;2, 1973.

Platt, C.M.R.: Remote sounding of high clouds: I. Calculation of visible and infrared optical properties from lidar and radiometer measurements, J. Appl. Meteorol. Clim., 18(9), 1130-1143, https://doi.org/10.1175/1520-0450(1979)018<1130:RSOHCI>2.0.CO;2, 1979.

Protat, A., Delanoë, J., Plana-Fattori, A., May, P.T. and O'Connor, E.J.: The statistical properties of tropical ice clouds generated by the West African and Australian monsoons, from ground-based radar-lidar observations. Q.J.R. Meteorol. Soc., 136, 345-363, https://doi.org/10.1002/qj.490, 2010.

Protat, A., Delanoë, J., May, P. T., Haynes, J., Jakob, C., O’Connor, E., Pope, M., and Wheeler, M. C.: The variability of tropical ice cloud properties as a function of the large-scale context from ground-based radar-lidar observations over Darwin, Australia, Atmos. Chem. Phys., 11, 8363-8384, https://doi.org/10.5194/acp-11-8363-2011, 2011.

Radenz, M., Bühl, J., Seifert, P., Baars, H., Engelmann, R., Barja González, B., Mamouri, R.-E., Zamorano, F., and Ansmann, A.: Hemispheric contrasts in ice formation in stratiform mixed-phase clouds: disentangling the role of aerosol and dynamics with ground-based remote sensing, Atmos. Chem. Phys., 21, 17969-17994, https://doi.org/10.5194/acp-21-17969-2021, 2021.

405 Sassen, K. and Cho, B. S.: Subvisual-Thin Cirrus Lidar Dataset for Satellite Verification and Climatological Research, J. Appl. Meteorol. Clim., 31(11), 1275-1285, https://doi.org/10.1175/1520-0450(1992)031<1275:STCLDF>2.0.CO;2, 1992. 
Sassen, K. and Campbell, J. R.: A Midlatitude Cirrus Cloud Climatology from the Facility for Atmospheric Remote Sensing. Part I: Macrophysical and Synoptic Properties, J. Atmos. Sci., 58(5), 481-496, https://doi.org/10.1175/15200469(2001)058<0481:AMCCCF>2.0.CO;2, 2001.

410 Sassen, K., and Benson, S.: A Midlatitude Cirrus Cloud Climatology from the Facility for Atmospheric Remote Sensing. Part II: Microphysical Properties Derived from Lidar Depolarization, J. Atmos. Sci., 58(15), 2103-2112, https://doi.org/10.1175/15200469(2001)058<2103:AMCCCF>2.0.CO;2, 2001.

Sassen, K.: Indirect climate forcing over the western US from Asian dust storms, Geophys. Res. Lett., 29, https://doi.org/10.1029/2001GL014051, 2002.

415 Schmidt, J., Ansmann, A., Bühl, J., and Wandinger, U.: Strong aerosol-cloud interaction in altocumulus during updraft periods: lidar observations over central Europe, Atmos. Chem. Phys., 15, 10687-10700, https://doi.org/10.5194/acp-15-10687-2015, 2015.

Seifert, P., Ansmann, A., Müller, D., Wandinger, U., Althausen, D., Heymsfield, A. J., Massie, S. T., and Schmitt, C.: Cirrus optical properties observed with lidar, radiosonde, and satellite over the tropical Indian Ocean during the aerosol-polluted northeast and clean maritime southwest monsoon, J. Geophys. Res., 112, D17205, https://doi.org/10.1029/2006JD008352, 2007.

Seifert, P., Ansmann, A., Mattis, I., Wandinger, U., Tesche, M., Engelmann, R., Müller, D., Pérez, C., and Haustein, K.: Saharan dust and heterogeneous ice formation: eleven years of cloud observations at a central European EARLINET site, J. Geophys. Res., 115, D20201, https://doi.org/10.1029/2009JD013222, 2010.

Seifert, P., Ansmann, A., Groß, S., Freudenthaler, V., Heinold, B., Hiebsch A., Mattis, I., Schmidt, J., Schnell, F., Tesche, M., Wandinger, U., and Wiegner, M.: Ice formation in ash-influenced clouds after the eruption of the Eyjafjallajökull volcano in April 2010, J. Geophys. Res., 116, D00U04, https://doi.org/10.1029/2011JD015702, 2011.

Seifert, P., Kunz, C., Baars, H., Ansmann, A., Bühl, J., Senf, F., Engelmann, R., Althausen, D., and Artaxo, P.: Seasonal variability of heterogeneous ice formation in stratiform clouds over the Amazon Basin, Geophys. Res. Lett., 42, 5587-5593, https://doi.org/10.1002/2015GL064068, 2015.

Sellitto, P., Bucci, S., and Legras, B.: Comparison of ISS-CATS and CALIPSO-CALIOP Characterization of High Clouds in the Tropics, Remote Sens., 12, 3946, https://doi.org/10.3390/rs12233946, 2020.

Solomon, A., Shupe, M. D., and Miller, N. B.: Cloud-Atmospheric Boundary Layer-Surface Interactions on the Greenland Ice Sheet during the July 2012 Extreme Melt Event, J. Clim., 30, 3237-3252, https://doi.org/10.1175/JCLI-D-16-0071.1, 2017.

Tesche, M., Achtert, P., and Pitts, M. C.: On the best locations for ground-based polar stratospheric cloud (PSC) observations, Atmos. Chem. Phys., 21, 505-516, https://doi.org/10.5194/acp-21-505-2021, 2021.

435 Winker, D. M., Vaughan, M. A., Omar, A., Hu, Y., Powell, K. A., Liu, Z., Hunt, W. H., and Young, S. A.: Overview of the CALIPSO Mission and CALIOP Data Processing Algorithms, J. Atmos. Ocean. Techn., 26, 2310-2323, https://doi.org/10.1175/2009JTECHA1281.1, 2009.

Yi, Y., Yi, F., Liu, F., Zhang, Y., Yu, C., and He, Y.: Microphysical process of precipitating hydrometeors from warm-front mid-level stratiform clouds revealed by ground-based lidar observations, Atmos. Chem. Phys., 21, 17649-17664, https://doi.org/10.5194/acp-21-17649-2021, 2021.

440 Yorks, J. E., Hlavka D. L., Vaughan, M. A., McGill, M. J., Hart, W. D., Rodier, S. D., and Kuehn, R. E.: Airborne validation of cirrus cloud properties derived from CALIPSO lidar measurements: Spatial properties, J. Geophys. Res.: Atmos., 116, D19207, https://doi.org/10.1029/2011JD015942, 2011. 
https://doi.org/10.5194/amt-2022-34

Preprint. Discussion started: 10 February 2022

(c) Author(s) 2022. CC BY 4.0 License.

(c) (1)

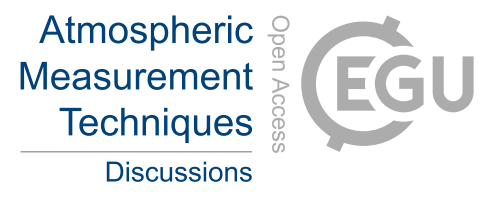

Yorks, J. E., McGill, M. J., Palm, S. P., Hlavka, D. L., Selmer, P. A., Nowottnick, E. P., Vaughan, M. A., Rodier, S. D., and Hart, W. D.: An overview of the CATS level 1 processing algorithms and data products, Geophys. Res. Lett., 43, 4632-4639, https://doi.org/10.1002/2016GL068006, 2016a.

Yorks, J. E., Palm, S. P., McGill, M. J., Hlavka, D. L., Hart, W. D., Selmer, P. A., and Nowottnick, E.: CATS Algorithm Theoretical Basis Document, Level 1 and Level 2 Data Products, release 1.2, available at https://cats.gsfc.nasa.gov/media/docs/CATS_ATBD.pdf (last access: 13 December 2021), 2016b. 
https://doi.org/10.5194/amt-2022-34

Preprint. Discussion started: 10 February 2022

(c) Author(s) 2022. CC BY 4.0 License.

(c) (i)

\section{Atmospheric \\ Measurement Techniques \\ Discussions}

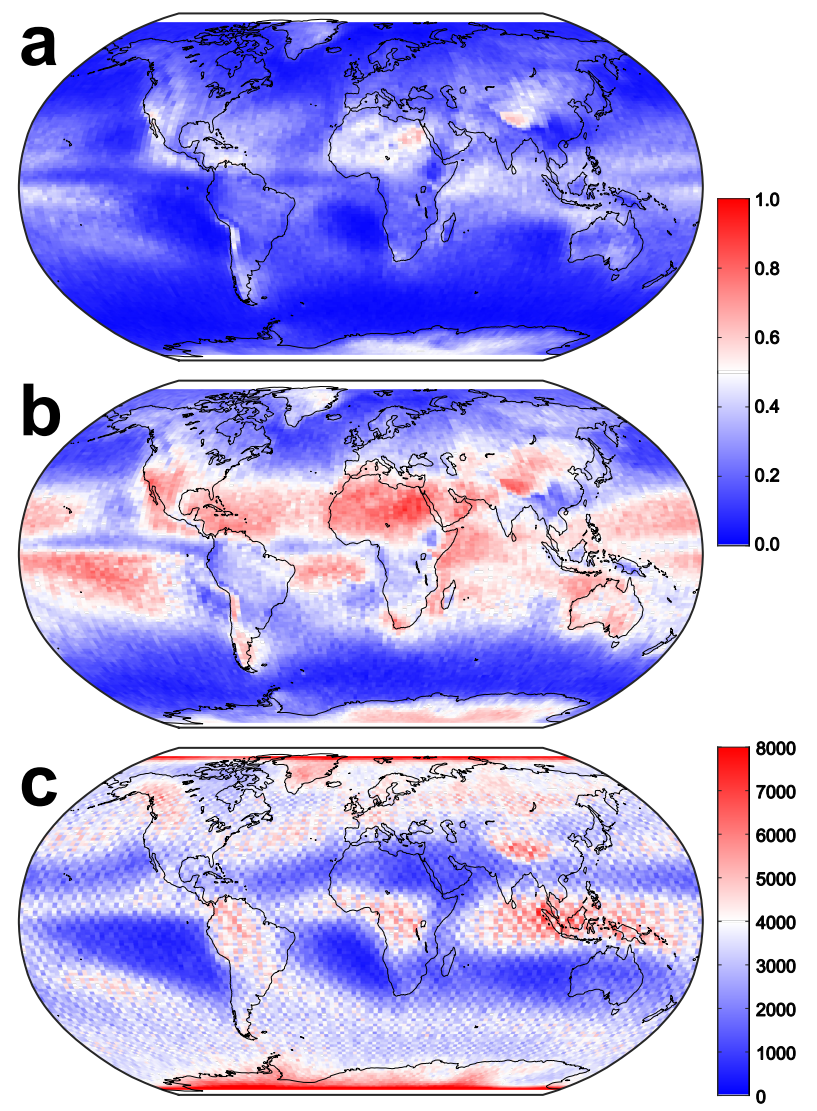

Figure 1. Global distribution of (a) the ratio of CALIPSO profiles that contain cirrus clouds in the absence of opaque low- and mid-level clouds versus all cloudy profiles, (b) the ratio of CALIPSO profiles that contain cirrus clouds in the absence of opaque low- and mid-level clouds versus all cirrus-containing cloudy profiles, and (c) the number of cirrus-containing cloudy profiles per grid box.

Table 1. Number of considered CALIOP cloud profiles per category. Ac refers to transparent altocumulus. Ci only and Ac only refer to those profiles in which the view of the respective cloud type from ground would not be distorted by the absence of opaque clouds underneath.

\begin{tabular}{lrrrrrr}
\hline category & all & cloudy & cloudy with Ci & cloudy with Ac & Ci only & Ac only \\
\hline all & 230630832 & 150777153 & 66173606 & 34172890 & 28955077 & 19633799 \\
day & 122579072 & 78588786 & 31182825 & 16578597 & 14016073 & 9523533 \\
night & 108051760 & 72188367 & 34990781 & 17594293 & 14939004 & 10110266 \\
\hline DJF & 58489753 & 37591867 & 15846490 & 8834292 & 6792929 & 5032950 \\
MAM & 58479316 & 37906882 & 17061030 & 8928728 & 7564229 & 5126397 \\
JJA & 55976733 & 37154450 & 16709624 & 8084125 & 7460288 & 4839669 \\
SON & 57685030 & 38123954 & 16556462 & 8325745 & 7137631 & 4634783 \\
\hline
\end{tabular}


https://doi.org/10.5194/amt-2022-34

Preprint. Discussion started: 10 February 2022

(c) Author(s) 2022. CC BY 4.0 License.

\section{Atmospheric Measurement Techniques \\ Discussions}

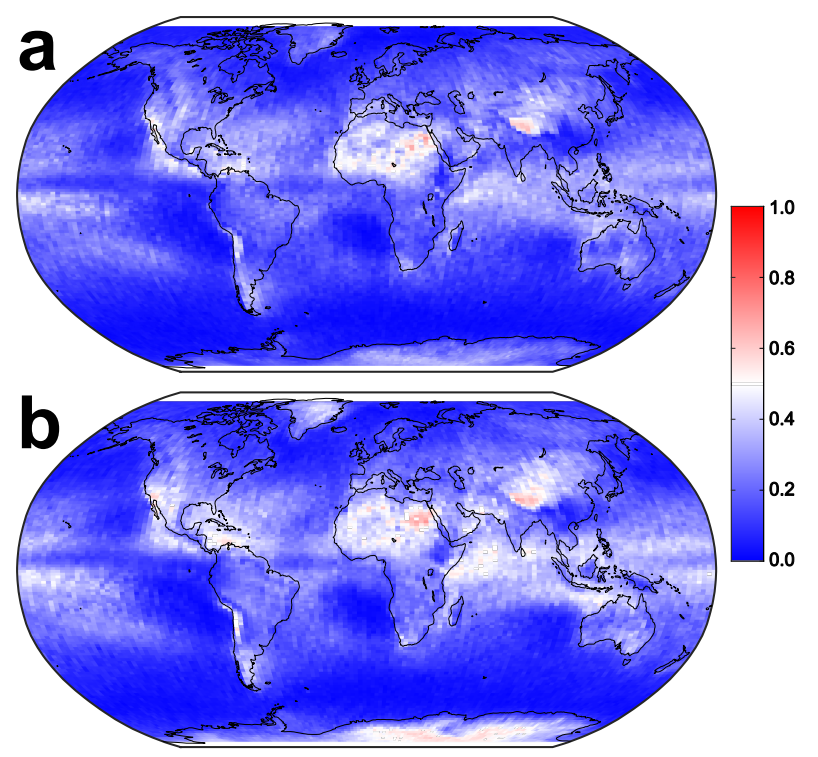

Figure 2. Same as Figure 1a but separated according to CALIPSO observations during (a) day and (b) night.

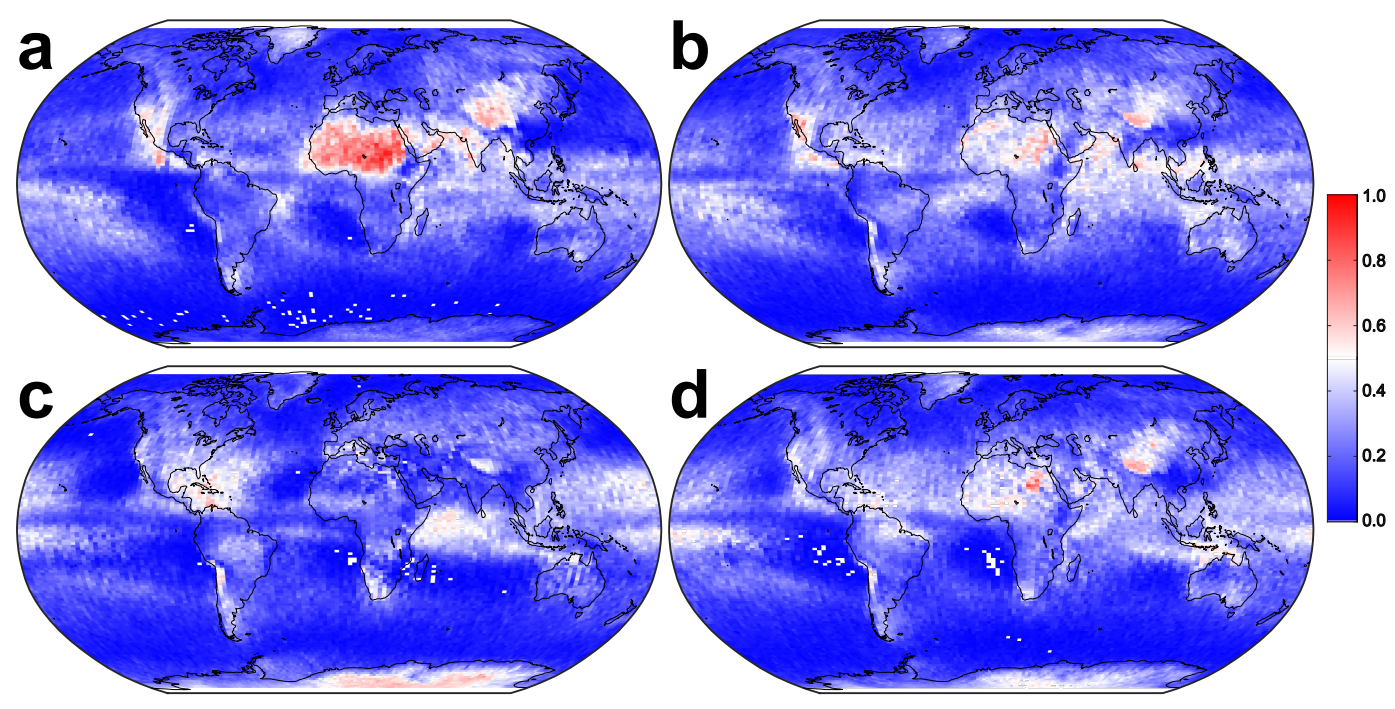

Figure 3. Same as Figure 1a but for the three-month periods (a) DJF, (b) MAM, (c) JJA, and (d) SON. 
https://doi.org/10.5194/amt-2022-34

Preprint. Discussion started: 10 February 2022

(c) Author(s) 2022. CC BY 4.0 License.

\section{Atmospheric Measurement Techniques \\ Discussions}

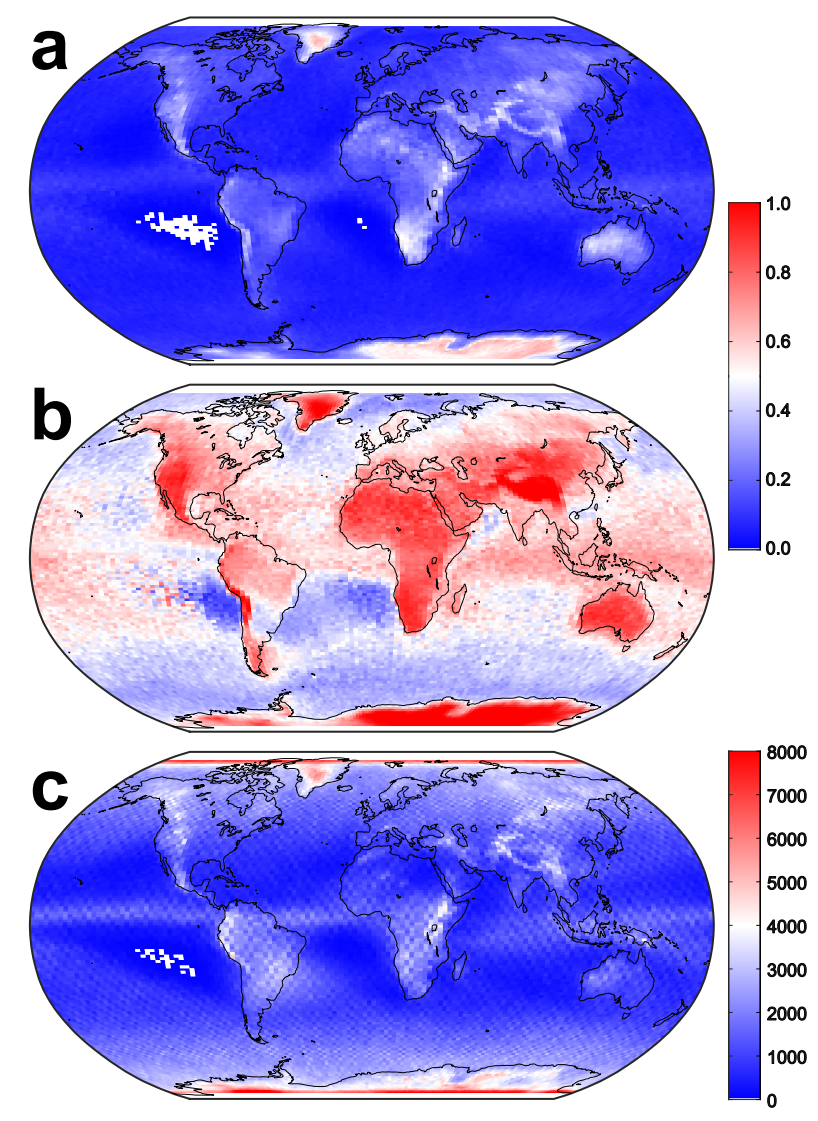

Figure 4. Global distribution of (a) the ratio of CALIPSO profiles that contains transparent altocumulus in the absence of opaque low-level clouds versus all cloudy profiles, (b) the ratio of CALIPSO profiles that contain transparent altocumulus in the absence of opaque low-level clouds versus all cloudy profiles that contain this cloud type, and (c) the number of cloudy profiles per grid box that contain altocumulus transparent. 
https://doi.org/10.5194/amt-2022-34

Preprint. Discussion started: 10 February 2022

(c) Author(s) 2022. CC BY 4.0 License.

\section{Atmospheric Measurement Techniques Discussions}

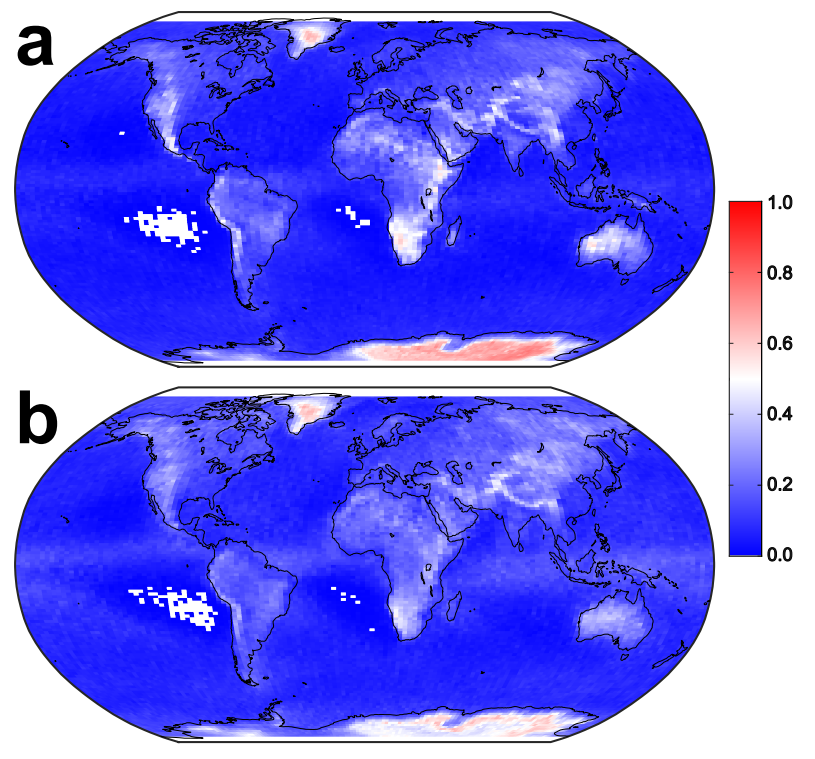

Figure 5. Same as Figure 4a but separated according to CALIPSO observations during (a) day and (b) night.

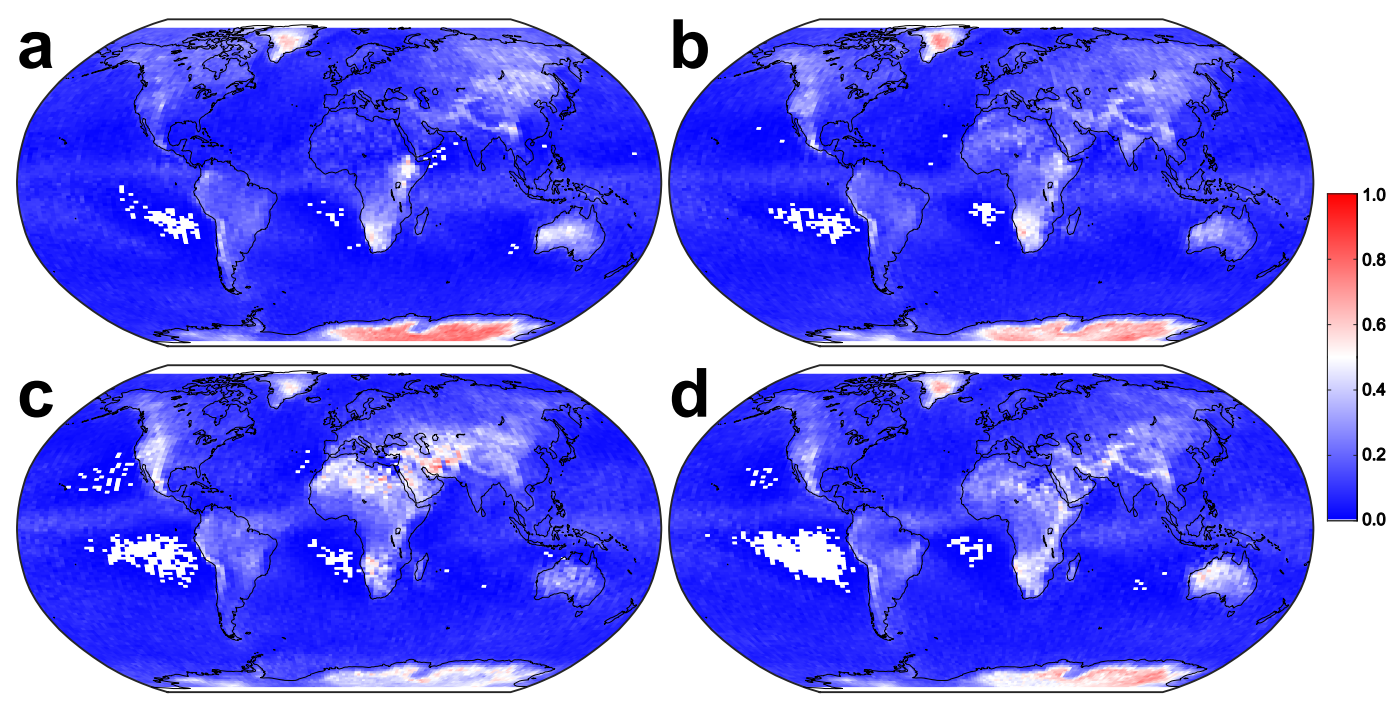

Figure 6. Same as Figure 4a but for the three-month periods (a) DJF, (b) MAM, (c) JJA, and (d) SON. 
https://doi.org/10.5194/amt-2022-34

Preprint. Discussion started: 10 February 2022

(c) Author(s) 2022. CC BY 4.0 License.
Atmospheric

Measurement

Techniques

Discussions

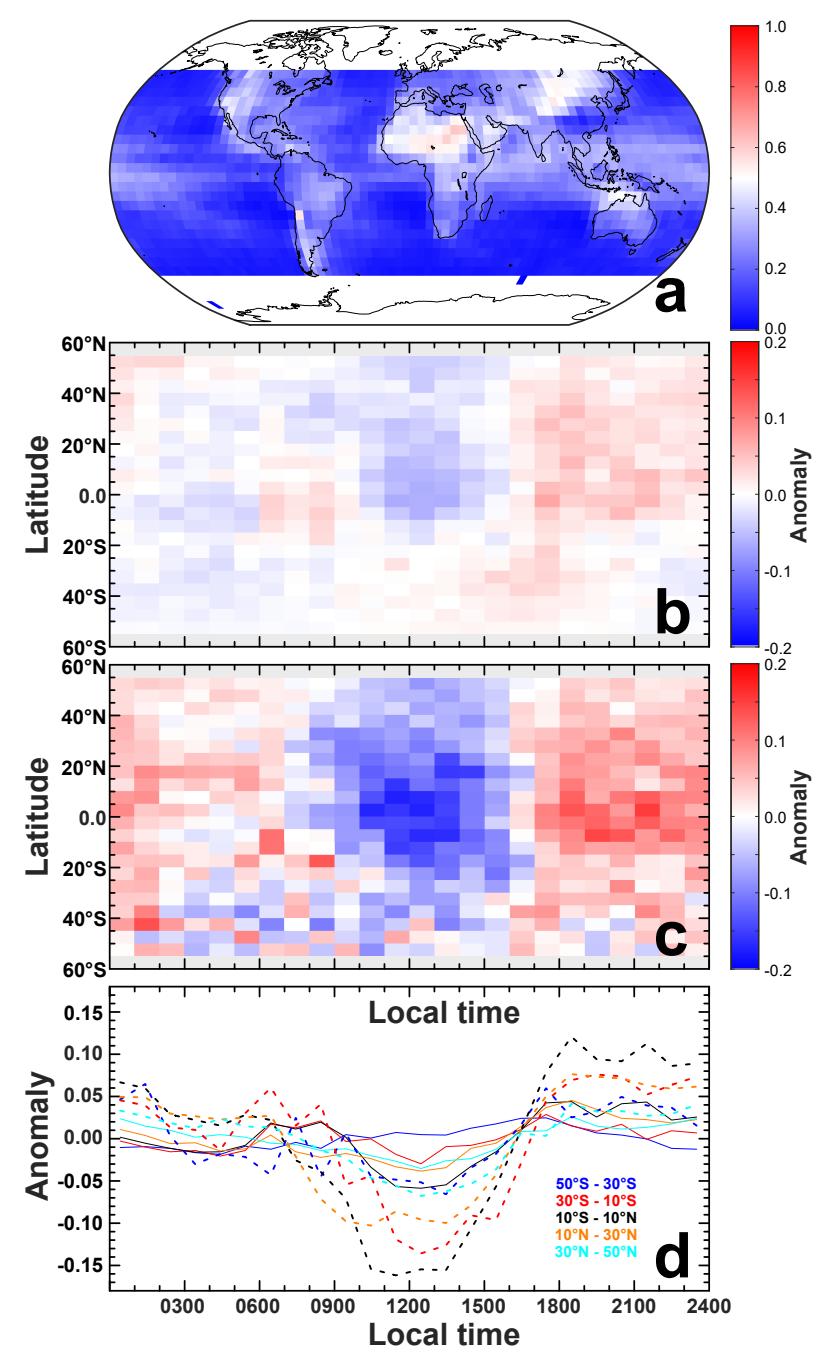

Figure 7. Occurrence rate of isolated ice clouds in CATS observations between March 2015 and October 2017 as (a) global distribution, anomaly in the diurnal variation of the zonal distribution over all surfaces (b) and land only (c), and (d) anomaly in the diurnal variation of the zonal average in five latitude bands: $50^{\circ} \mathrm{S}-30^{\circ} \mathrm{S}$ (blue), $30^{\circ} \mathrm{S}-10^{\circ} \mathrm{S}$ (red), $10^{\circ} \mathrm{S}-10^{\circ} \mathrm{N}$ (black), $10^{\circ} \mathrm{N}-30^{\circ} \mathrm{N}$ (orange), and $30^{\circ} \mathrm{N}-50^{\circ} \mathrm{N}$ (light blue) over all surfaces (solid) and land only (dashed). The anomaly is calculated as the difference between hourly values and the daily mean value. 
https://doi.org/10.5194/amt-2022-34

Preprint. Discussion started: 10 February 2022

(c) Author(s) 2022. CC BY 4.0 License.

\section{Atmospheric Measurement Techniques}

Discussions

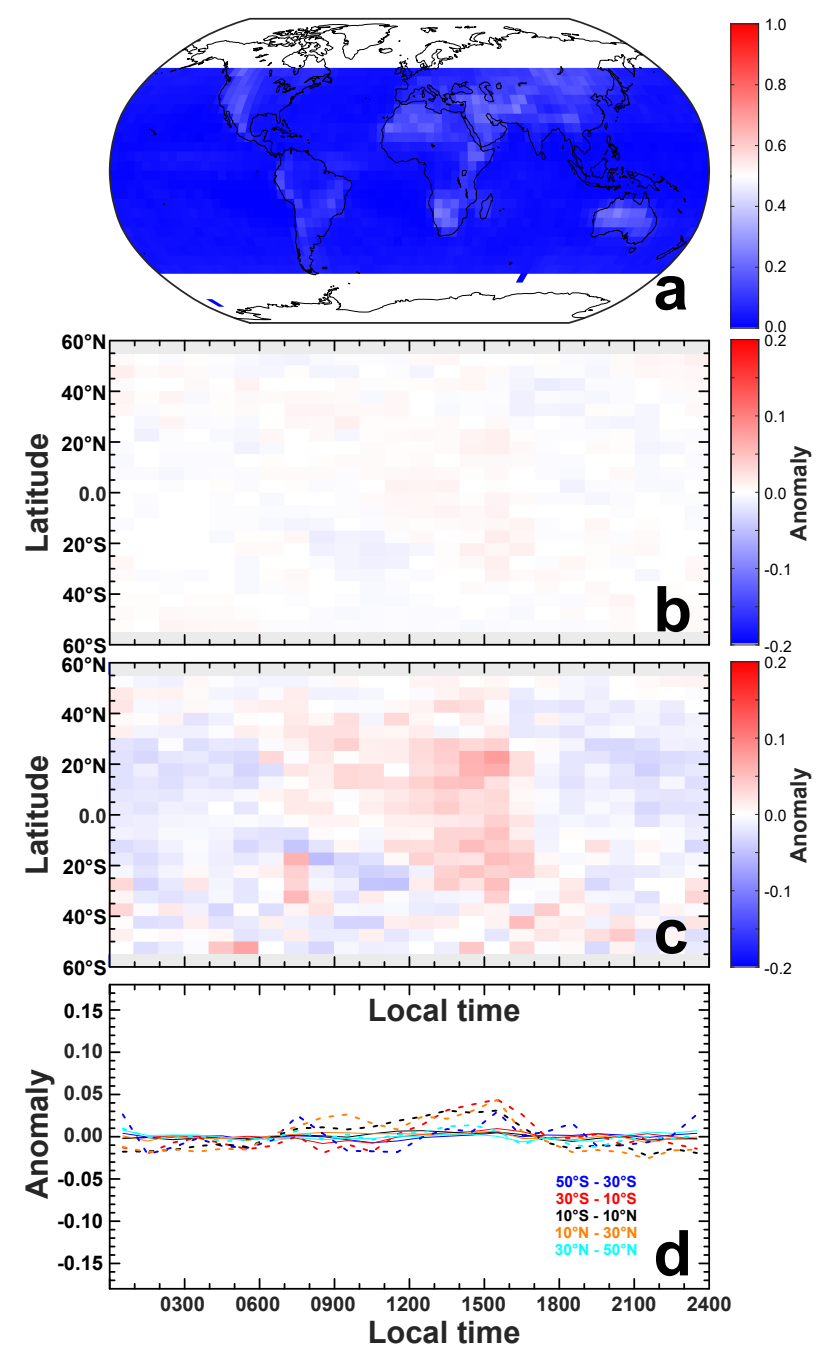

Figure 8. Occurrence rate of isolated mid-level clouds in CATS observations between March 2015 and October 2017 as (a) global distribution, anomaly in the diurnal variation of the zonal distribution over all surfaces (b) and land only (c), and (d) anomaly in the diurnal variation of the zonal average in five latitude bands: $50^{\circ} \mathrm{S}-30^{\circ} \mathrm{S}$ (blue), $30^{\circ} \mathrm{S}-10^{\circ} \mathrm{S}$ (red), $10^{\circ} \mathrm{S}-10^{\circ} \mathrm{N}$ (black), $10^{\circ} \mathrm{N}-30^{\circ} \mathrm{N}\left(\right.$ orange), and $30^{\circ} \mathrm{N}-50^{\circ} \mathrm{N}$ (light blue) over all surfaces (solid) and land only (dashed). The anomaly is calculated as the difference between hourly values and the daily mean value. 
https://doi.org/10.5194/amt-2022-34

Preprint. Discussion started: 10 February 2022

(c) Author(s) 2022. CC BY 4.0 License.

\section{Atmospheric Measurement Techniques \\ Discussions}
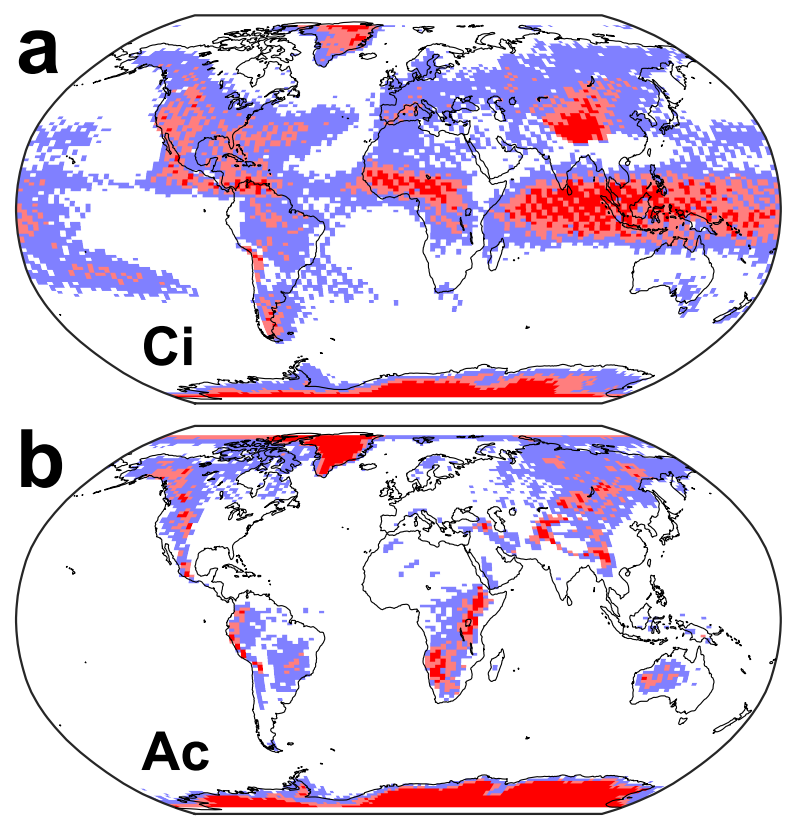

Figure 9. Overview of the best regions for placing a ground-based lidar for observing high (a) and mid-level (b) clouds derived from multiplying the data in Figures 1a and 4a with the normalised number of profiles per grid box, i.e. Figure 1c divided by 13806 and Figure $4 \mathrm{c}$ 11690, respectively. The colours refer to the factors for meeting suitable conditions for ground-based lidar observations of the two cloud types. For cirrus clouds, the colours mark the ranges 0.000 to 0.0399 (white), 0.0400 to 0.0799 (light blue), 0.0800 to 0.1199 (light red), and $>0.1200$ (red). The corresponding ranges for altocumulus clouds are 0.00 to $0.0299,0.0300$ to $0.0599,0.0600$ to 0.0899 , and $>0.0900$. 
https://doi.org/10.5194/amt-2022-34

Preprint. Discussion started: 10 February 2022

(c) Author(s) 2022. CC BY 4.0 License.

(c) (i)

\section{Atmospheric Measurement \\ Techniques \\ Discussions}

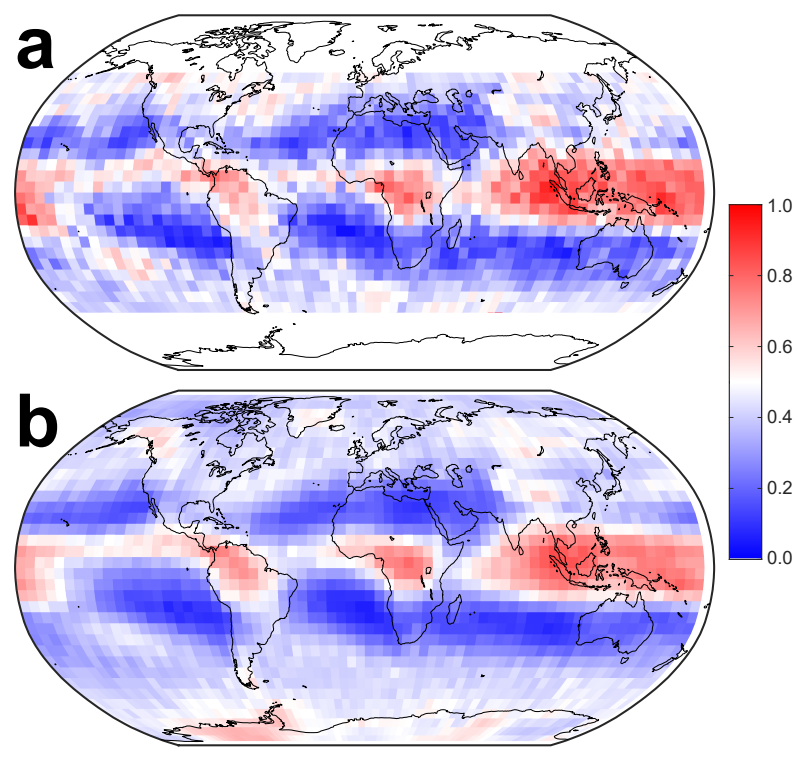

Figure A1. Global distribution of the fraction of cirrus clouds in observations with the CATS (a) and CALIPSO (b) lidars for the time period from March 2015 to October 2017. Only CATS data within \pm 1 hour around the fixed CALIPSO overpass times are considered.
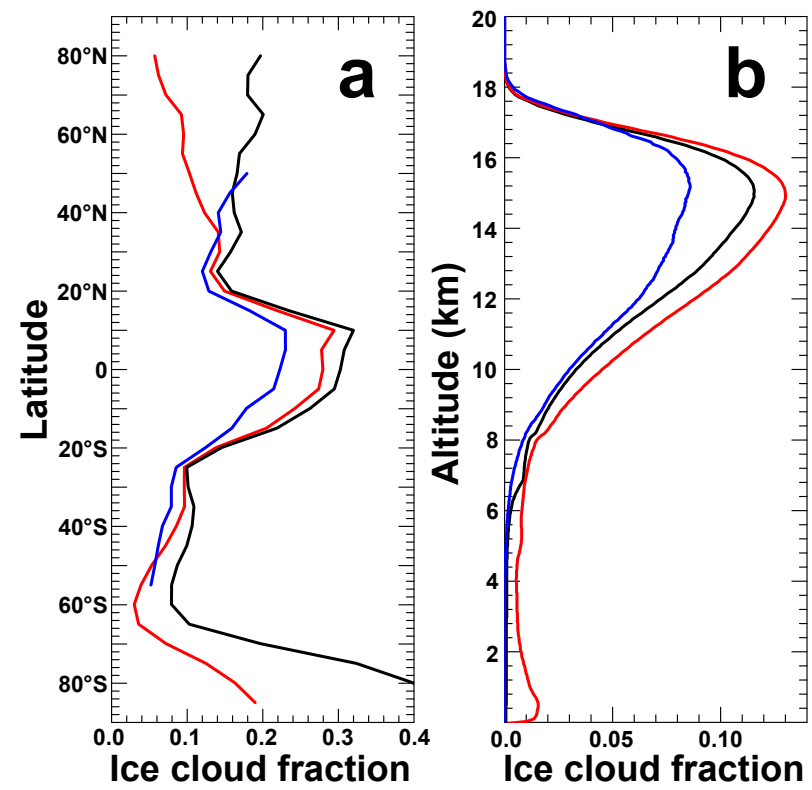

Figure A2. Latitudinal distribution (a) and height profiles (b) of the cloud fractions of isolated cirrus as seen by CALIPSO (black) and of isolated ice clouds as seen by CALIPSO (red) and CATS (blue) for the time period from March 2015 to October 2017. 
https://doi.org/10.5194/amt-2022-34

Preprint. Discussion started: 10 February 2022

(c) Author(s) 2022. CC BY 4.0 License.
Atmospheric

Measurement

Techniques

Discussions

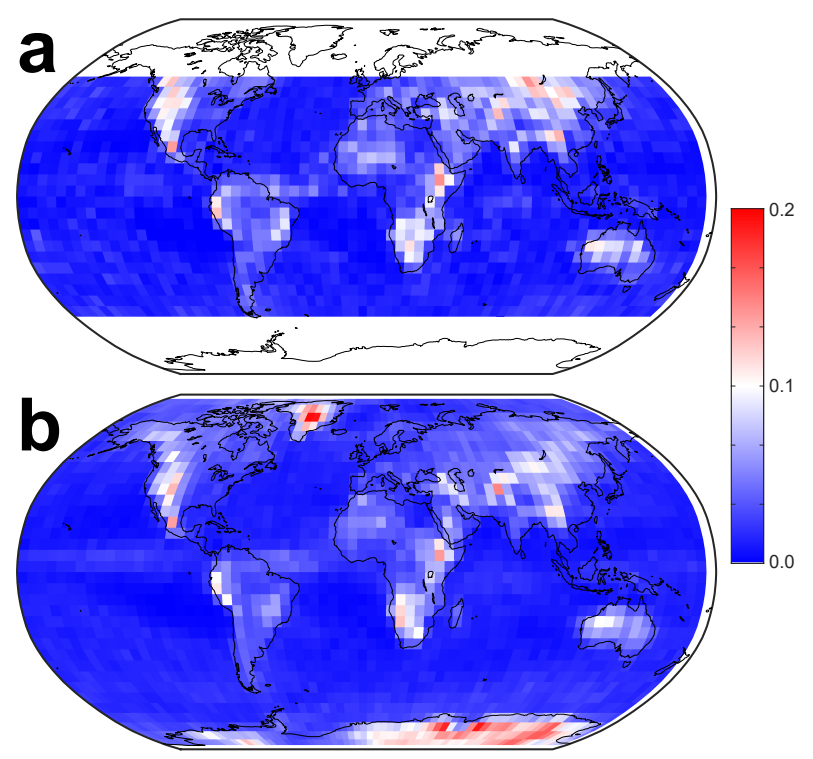

Figure A3. Global distribution of the fraction of mid-level clouds in observations with the CATS (a) and CALIPSO (b) lidars for the time period from March 2015 to October 2017.
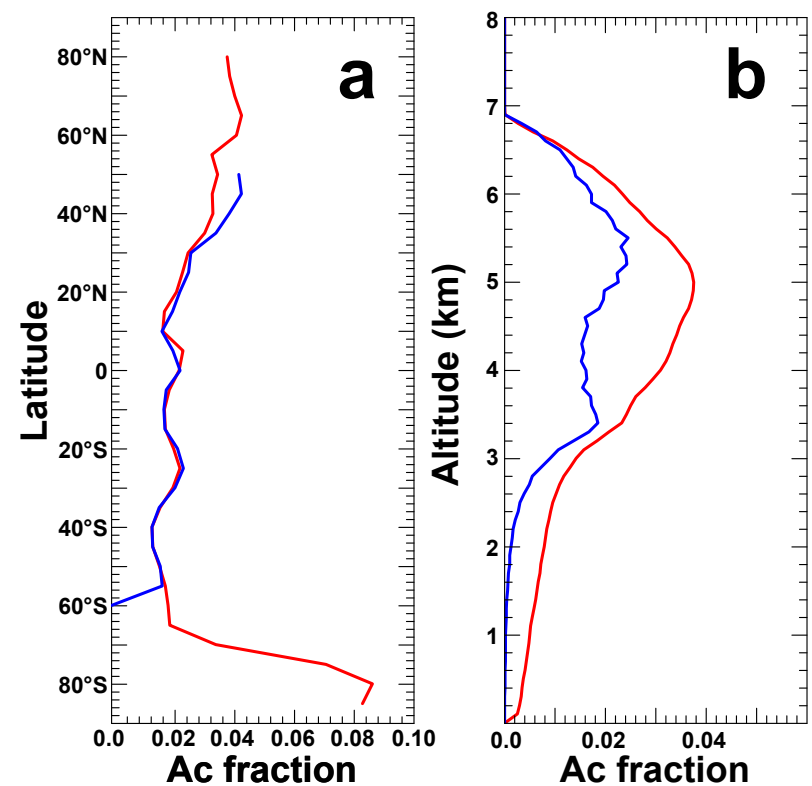

Figure A4. Latitudinal distribution (a) and height profiles (b) of the altocumulus cloud fraction as seen by CALIPSO (red) and CATS (blue) for the time period from March 2015 to October 2017. 